宿題報告

食道癌の発生と治療に関する臨床的ならびに実験的研究

\author{
日本医科大学第 1 外科 \\ 山下精 彦

\section{CLINICAL AND EXPERIMENTAL STUDIES ON THE HISTOGENESIS AND TREATMENT OF ESOPHAGEAL CANCER}

Kiyohiko YAMASHITA

First Department of Surgery, Nippon Medical School

\begin{abstract}
食道癌の発生と発育過程をヒト食道剖検例および切除例の325例とラット拉よびビーグル犬に実験 的に食道癌を作製し組織学的に検討した。 ヒト，ラット，イヌの食道癌は異型上皮を前癌病変とし発 生することが強く示唆され, さらに発癌の促進因子の一つに細菌の関与が示睃された。 また, ヒ卜食 道胃接合部の予備細胞増殖を伴万扁平上皮化生は癌発生母地の一つと考号られた。食道癌の補助療法 として放射線療法（Linac），化学療法（油性ブレオマイシンの経口投与）と高圧酸素療法の三者併用 は実験食道癌ばかりでなくヒト食道癌にも有効であった。
\end{abstract}

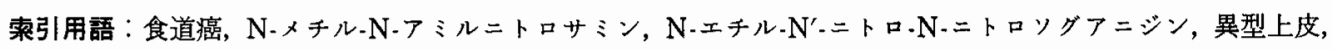
油性ブレオマイシン

はじめに

近年, 食道癌の診断と治療は著しく進歩したとはい 兄, 治療成績はいまだ満足すべきものではなく，その 最大因子は早期発見が困難で早期癌症例が少ないこと にある ${ }^{1)}$.そのため, 初期病変とその発育過程に関する 知見は極めて乏しい実情である。

そこで，ヒト剖検例と切除例および実験的食道癌を 材料としてその発生と発育過程について研究するとと もに補助療法がこれに及洔す影響について研究したの でこれらの研究成績を述べる.

\section{I. 食道癌の発生について}

1. ヒト食道癌の発生母地について

（1）剖検食道症例での検討

食道の扁平上皮癌の組織発生に着目し, 比較的小さ な癌の周囲粘膜, とくに異型上皮との関係を検討した.

材料とした食道は剖検例 264 , 切除例 61 の計325例(男 子215例，女子110例) である。

ヒト食道の切出し法はフォルマリン固定後, 食道胃 接合部のみ縦割し, 他は全食道を $5 \mathrm{~mm}$ 幅で全てをス テップ・セクションとして標本を作製し, 組織学的に

※第20回日消外会総会
検索した。

写真 1 は異型上皮で角化細胞が有棘細胞層に多数存 在し，基底層から傍基底層に異型細胞が認められ，中 等度異型上皮の像である。

このような異型上皮の出現頻度を表 1 のごとく, 各 年龄別に男子155例，女子96例の計251例について検討 すると，異型上皮は高龄者注ど頻度が高く，乙か子男 子は女子より高率であった。 また，これらのらち，と くに中一高度異型上皮をみると，40歳代以降にのみ存 在し男子は女子より高頻度に出現した。

ところで, 前癌病変の存在を精査するには進行癌で なく, 微小な癌周囲の変化を知ることが重要で, 全検 索 325 症例中に $1.0 \mathrm{~cm}$ 以下の微小癌は 7 例であった.

写真 2 は下部食道にみられた微小癌の組織像で, 上 段は弱拡大で異型上皮に囲まれていた。下段は強拡大 で左半分に癌, 右半分に異型上皮がみられ，両者は連 続的に移行し明瞭な境界を見い出すことはできなかっ た。中央部に基底膜を破る微小浸潤突起を認め, $1 \mathrm{~mm}$ 以下の微小癌でもすでに浸潤していた。

図 1 は癌周囲の粘膜を詳細に検索した 7 例中の代表 的な 3 例である。.上段は前述の症例で下部食道に径 1 $\mathrm{mm}$ 以下の数小癌周囲の異型上皮が認められる。中 
表 1

食道粘膜の異型上皮の年令別頻度

\begin{tabular}{|c|c|c|c|c|c|c|c|c|c|}
\hline (12) & th & The & 40 & F & w1 & 度 & & & 용t \\
\hline 年命 V & 男珄 & 女耻 & 小柆 & 男棈 & 女性 & 小蛢 & (s) & (5) & (5) \\
\hline $0 \sim 30$ & 12 & 8 & 20 & 1 & 0 & 1 & 8 & 0 & 5 \\
\hline $31-40$ & D & 11 & 19 & 1 & 1 & 2 & 13 & 9 & 11 \\
\hline $41-50$ & 17 & 13 & 30 & 3 & 1 & 4 & 18 & 且 & 13 \\
\hline $51 \sim 60$ & $3 !$ & 22 & 53 & 9 & 3 & 12 & 29 & 14 & 23 \\
\hline $61-70$ & 49 & 23 & 72 & 20 & 6 & 26 & 41 & 26 & 36 \\
\hline $71 \sim 90$ & 35 & 18 & 53 & 14 & 6 & 20 & 40 & 33 & 38 \\
\hline 812 & 3 & 1 & 4 & 2 & 0 & 2 & 67 & 0 & 50 \\
\hline 盒路 & 155 & 96 & 251 & 50 & 17 & 67 & 32 & 18 & 27 \\
\hline
\end{tabular}

食道粘膜の中〜高度異型上皮の年令別頻度

\begin{tabular}{|c|c|c|c|c|c|c|c|c|c|}
\hline \multirow{2}{*}{ 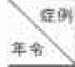 } & \multicolumn{3}{|c|}{ 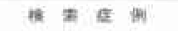 } & \multicolumn{3}{|c|}{ 中〜高度の異型上皮 } & \multirow{2}{*}{$\begin{array}{l}\text { Ptat } \\
\text { (S) }\end{array}$} & \multirow{2}{*}{$\begin{array}{l}\text { 林) } \\
\text { (46) }\end{array}$} & \multirow{2}{*}{ 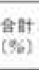 } \\
\hline & 裎性 & 支性 & What & 男住 & 安挂 & Whit & & & \\
\hline $0 \rightarrow 30$ & 12 & 8 & 20 & 0 & $\circ$ & o & 0 & $\circ$ & $\circ$ \\
\hline $31 \sim 40$ & 8 & 11 & 19 & 0 & 0 & 0 & 0 & 0 & a \\
\hline $41-30$ & 17 & 13 & 30 & 1 & o & i & 6 & o & 3 \\
\hline $51-60$ & 31 & 22 & 53 & 3 & $\circ$ & 3 & 10 & 0 & 6 \\
\hline $61 \sim 70$ & 49 & 23 & 72 & 12 & 1 & 13 & 24 & 4 & 18 \\
\hline $71-80$ & 35 & 18 & 53 & 7 & 2 & 9 & 20 & 11 & 17 \\
\hline $81-$ & 3 & 1 & 4 & 1 & $\circ$ & 1 & 33 & 0 & 25 \\
\hline 全 it & 155 & 96 & 251 & 24 & 3 & 27 & 15 & 3 & 11 \\
\hline
\end{tabular}

段は広範な異型上皮を伴ない連続して中部食道に多発 する癌巣が認められる。下段は癌巣と異型上皮とがは なれて存在している。

これらの 7 例をまとめると癌巣が異型上皮と接する もの 3 例, 異型上皮と接しないものや存在しないもの 各 1 例で 2 例は癌巣が粘膜固有層から粘膜下層に存在 していた.

写真 3 の左悢道癌切除標本の固有食道腺導管上皮 で高度の過形成と上皮細胞の核の大小不同の著明な異 型上皮がみられる. 右は径約 $1.0 \mathrm{~cm}$ の煞小食道癌で, 粘膜固有層から粘膜下層に癌巣が存在し, 正常上皮で 拉おれている，左の例と考文合わせると右の例は導 管上皮由来の癌であることを示唆している.

このような導管上皮の過形成は，全検索例の34\%に 存在するが年齢との一定の関係はなく，乙かも異型性 を示するのはわずかに $3 \%$ \%でた。しかし，微小癌 7 例中 2 例に存在していた事実は固有食道腺導管上皮 由来の扁平上皮癌も存在するものと思われた23).

（2）切除例の食道胃接合部についての検討

剖検例の食道胃接合部に子宮頝部に認める予備細胞 增殖を伴ら扁平上皮化生に類似した病変を見いだした ので,この点につき胃, 食道癌の男子81例，女子29例 の計110例の切除例について食道胃接合部を

I 型：噴門腺が食道上皮下に存在しない.
II 型：食道上皮下に連続的に噴門腺が存在する.

III型：固有食道腺が円柱上皮に開ロしている（バ レット食道).

の 3 型に分類し検討すると，表 2 のごとく，予備細 胞増殖や扁平上皮化生は $24 \%$ に存在したが年龄や男女 差はみられなかった。 さらに写真 4 は食道上皮から下 にのびる扁平上皮化生巣であるが，化生巣の上皮細胞 は扁平化し結節性増殖や異型を示している。このよう な食道胃接合部の扁平上皮化生宩の異型化は，前述の 予備細胞増殖を伴亏扁平上皮化生巣からの扁平上皮癌 の発生を強く示崚する所見と考壳られる4).

表 2 食道胃接合部領域の予備細胞堌殖の年齡分布

\begin{tabular}{|c|c|c|c|}
\hline 年舫 & 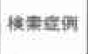 & 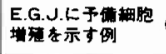 & $(\%)$ \\
\hline-40 & 8 & 2 & (25) \\
\hline $41 \sim 50$ & 16 & 4 & (25) \\
\hline $51 \sim 60$ & 23 & 8 & (35) \\
\hline $.61 \rightarrow 70$ & 38 & 6 & (16) \\
\hline $71 \sim$ & 25 & 6 & (24) \\
\hline It & 110 & 26 & (24) \\
\hline 舁 性 & 81 & 20 & $(25)$ \\
\hline 女 化 & 29 & 6 & (2i) \\
\hline
\end{tabular}

（3）ヒト食道癌の進展

進行癌に伴う上皮内癌の先進部と正常上皮括よび上 皮内癌と基底膜との関係を超微形態学的に検討した。

万法は上皮内進展を伴ら進行食道癌11例の切除標本 を上皮内癌と正常上皮の移行部を電顕ブロックとして 基底膜に垂直もしくは水平に超薄切した。

写真 5 は癌細胞と正常細胞の移行部で, 左に正常扁 平上皮細胞，右に扁平上皮癌細胞，中央部に間質系の 細胞が認められる。このように両者の境界部の多くに は間質系の細胞が存在している。しかし写真 6 のよ5 に, 右は光顕像, 左はその電顕像であるが, この両者 の楕円型の細胞は同一の正常上皮細胞で癌細胞が間質 系細胞を介せずに直接接している像も少数例にみられ る。

つぎに，癌細胞と基底膜との関係を直線的な基底膜 を有する単純置換型と波状を呈する基底膜を有する粗 造増殖型の 2 型に分けて検討した。

写重 7 は粗造増殖型の上皮内癌細胞で, 極めて多数 の細胞質の偽足突起が基底膜を破って粘膜固有層に出 て和り，上皮内癌といって子電顕的には基底膜が多数 の破たんを来たしていることが判明した，右下方は癌 細胞の偽足突起の拡大像で，基底膜は破壊され，基底 
写真 1 異型上皮（Dannのケラトヒアリン染色, × 200, 67歳, 男子, 肺癌症例）

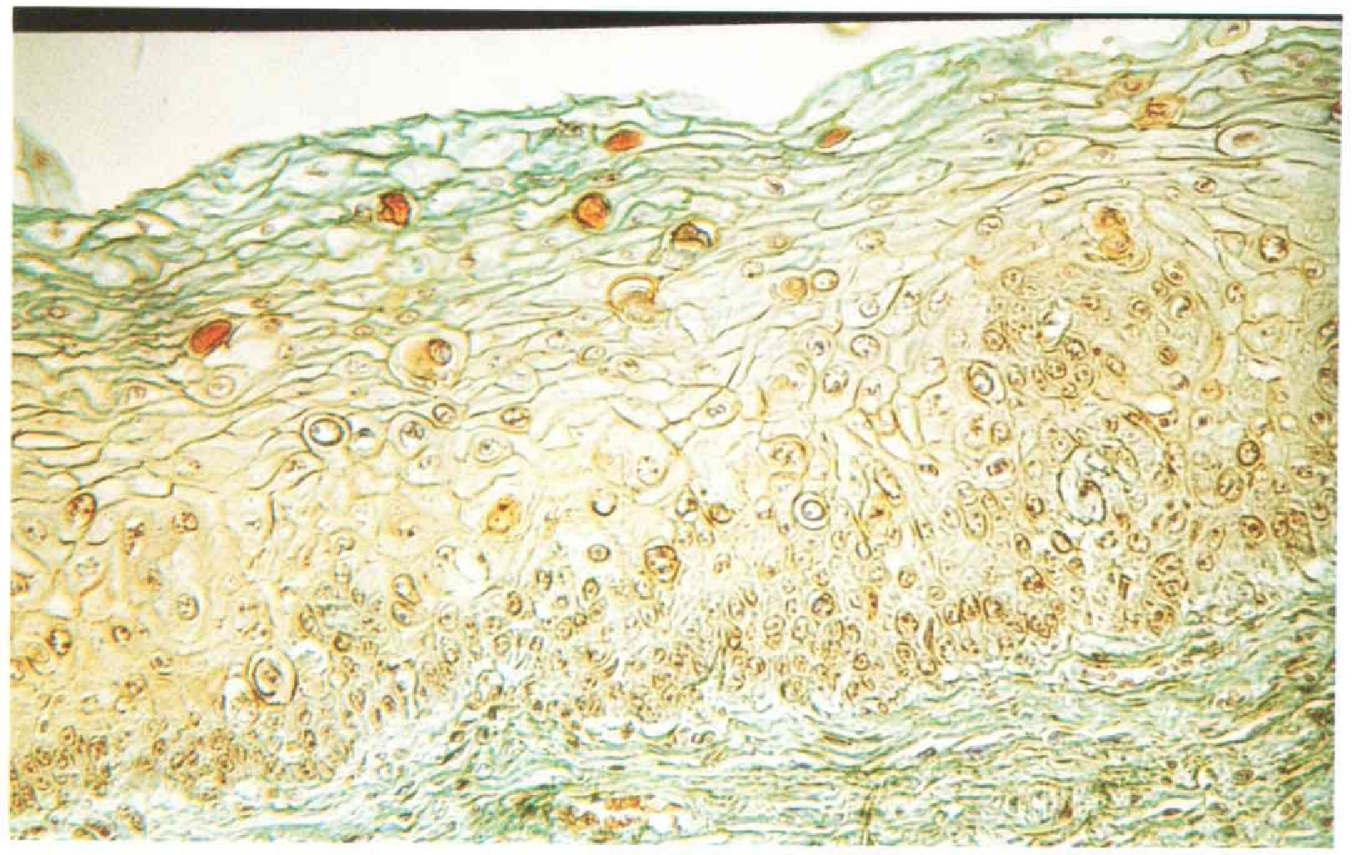

写真 2 (上段) 径 $1 \mathrm{~mm}$ 以下の微小癌, (下段) 左方に上皮内癌, 右方に異型上皮, 中央右に

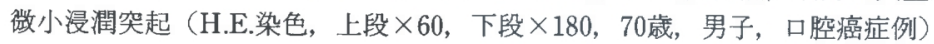
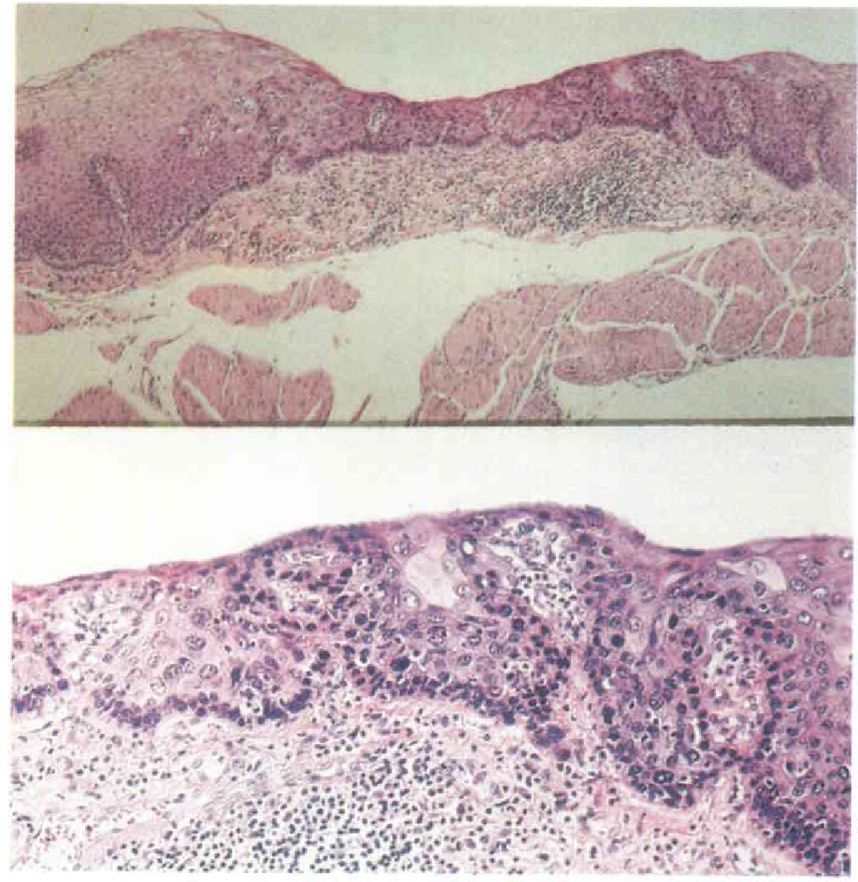
図 1 ヒト食道病変のシェーマ

(上段) 70 歳, 男子, 口腔癌 (中段) 67歳, 男子, 肺癌 (下段) 81 歳, 男子, 胃癌
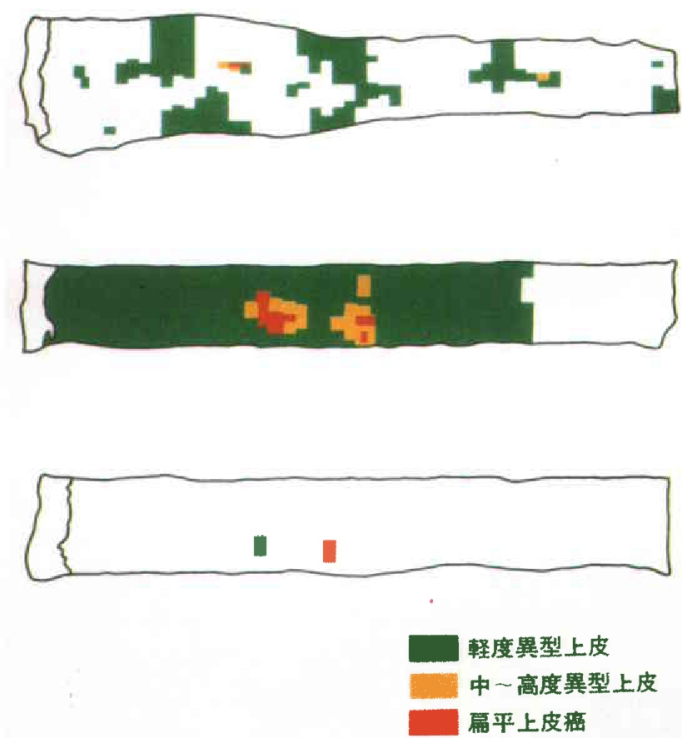

写真 4 食道・胃接合の予備細胞増殖を伴う扁平上皮化と異型化 $(\mathrm{H} . \mathrm{E}$ 染色 $\times 80)$

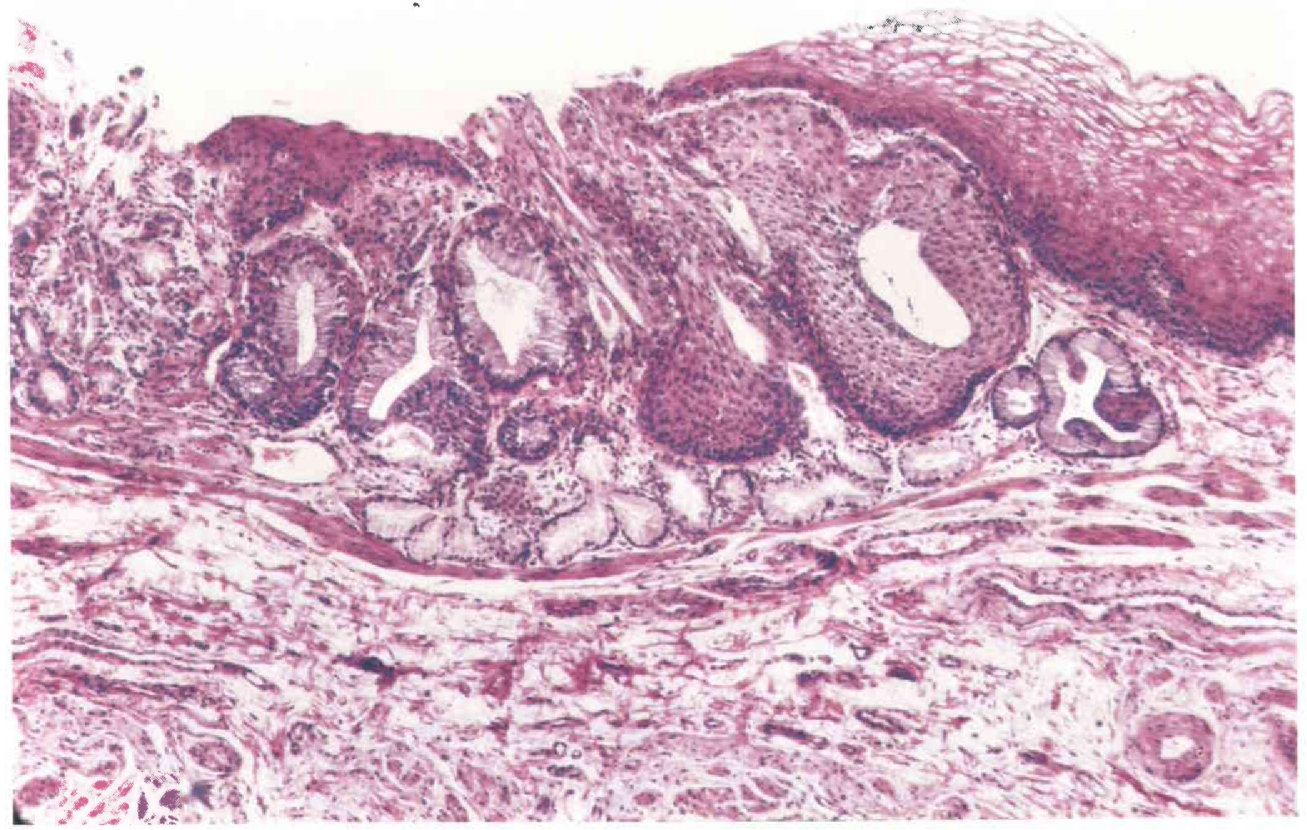


写真 8 MNAN によるラット食道の各病変 (H.E.染色)

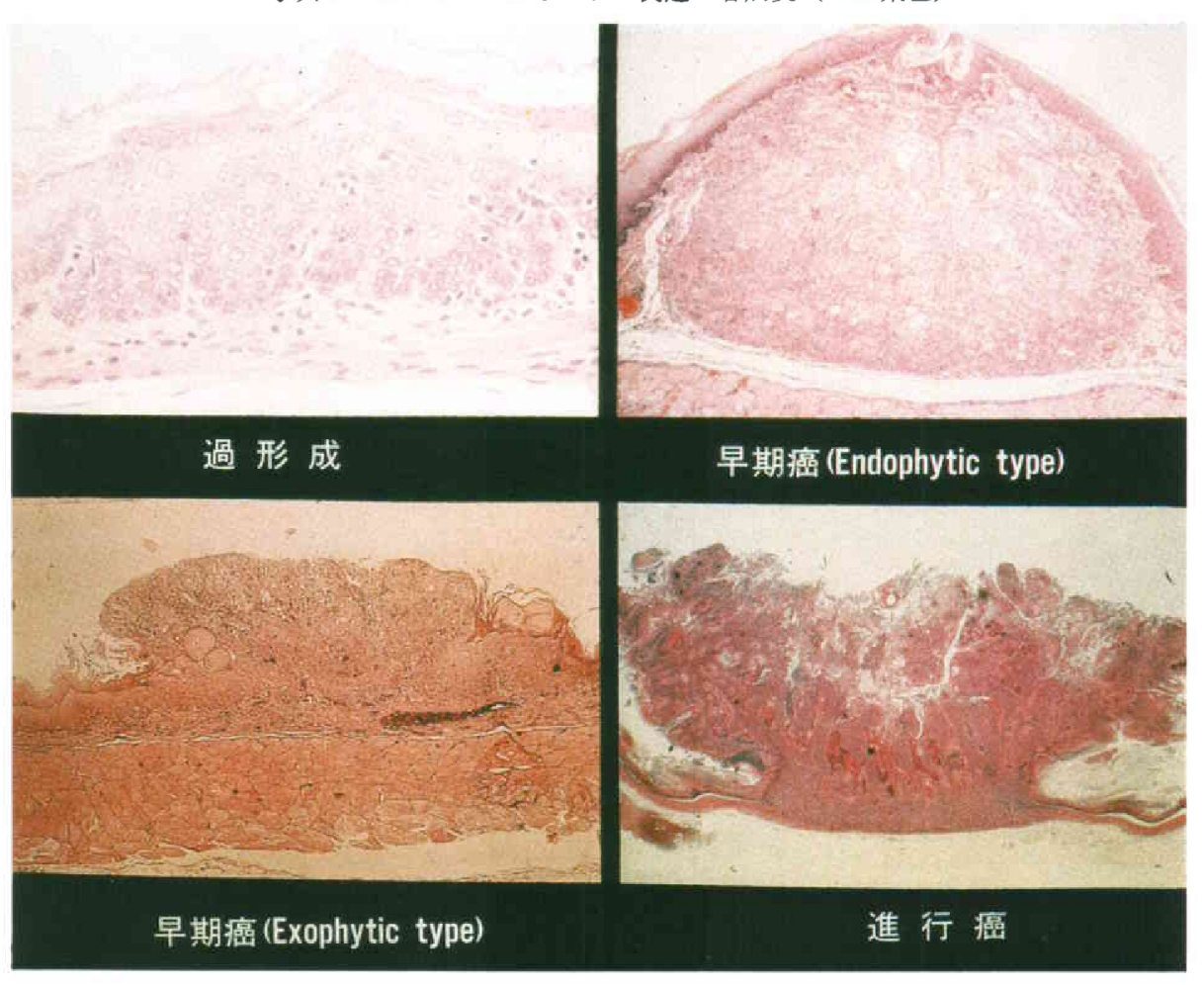

写真 9 ラット食道癌の肉眼所見（15週で屠殺剖検）

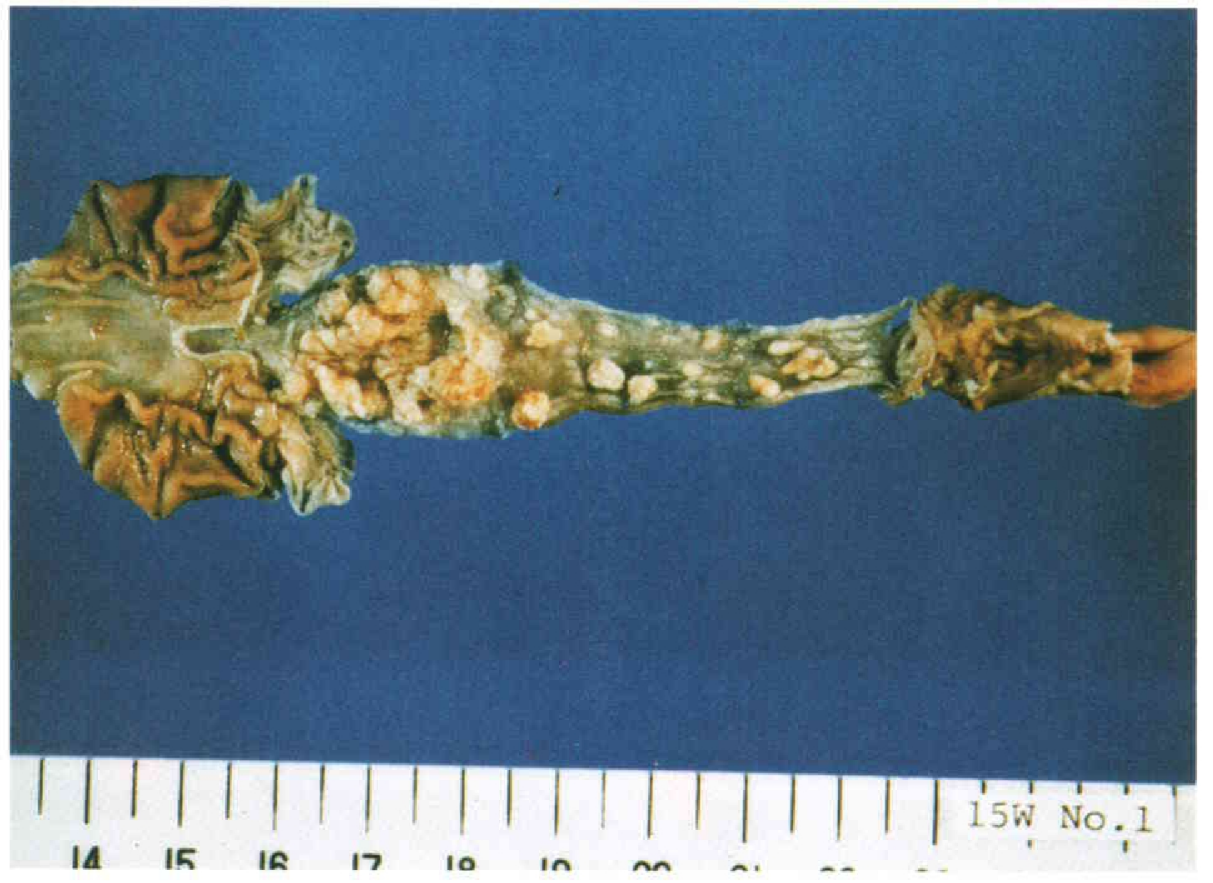


写真10 ラット食道の進行癌に括汁る各酵素の局在

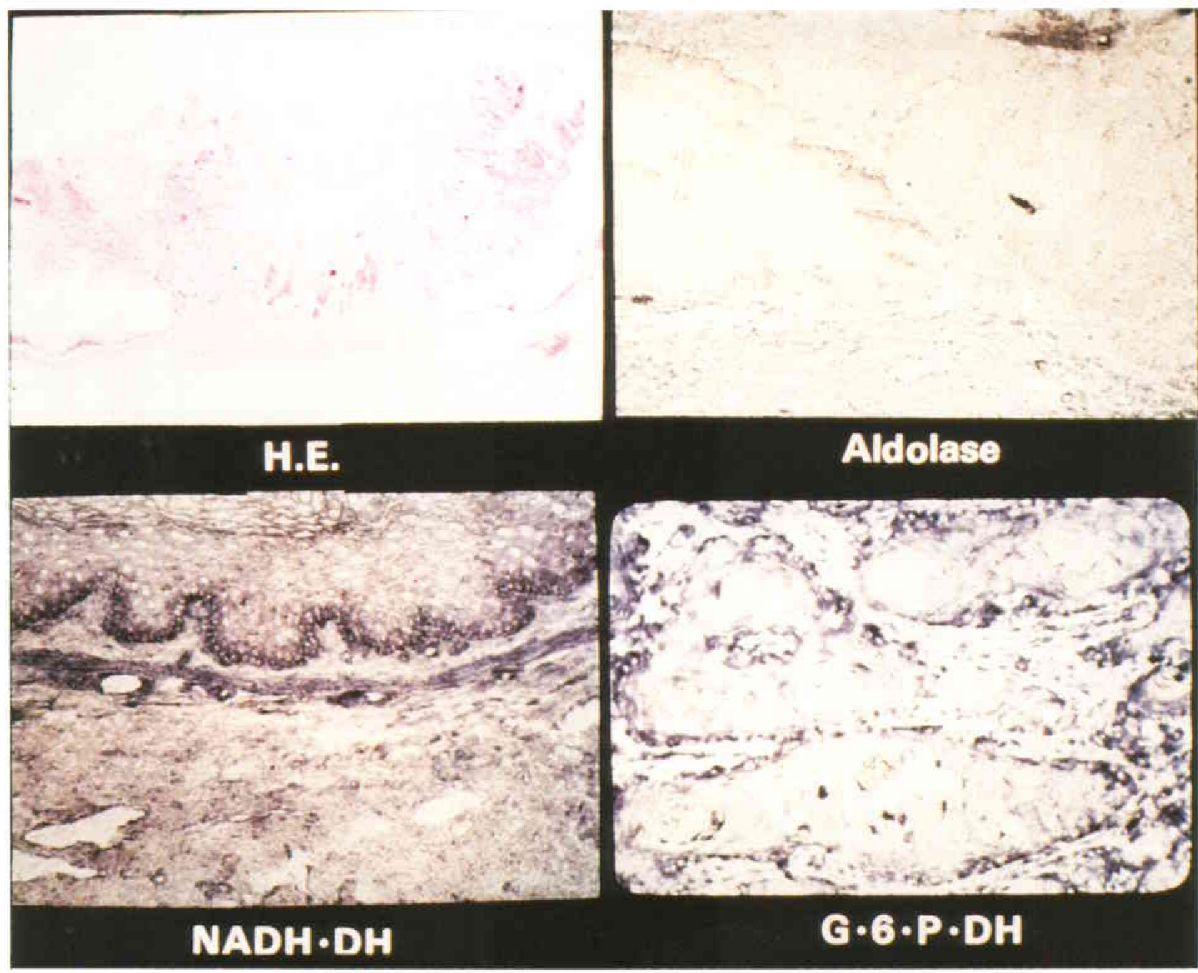

写真11 ビーグル犬食道に発生した異型上皮（左・実験開始 8 力月）, 癌 (右・30力月後) の内 視鏡と生検組織像

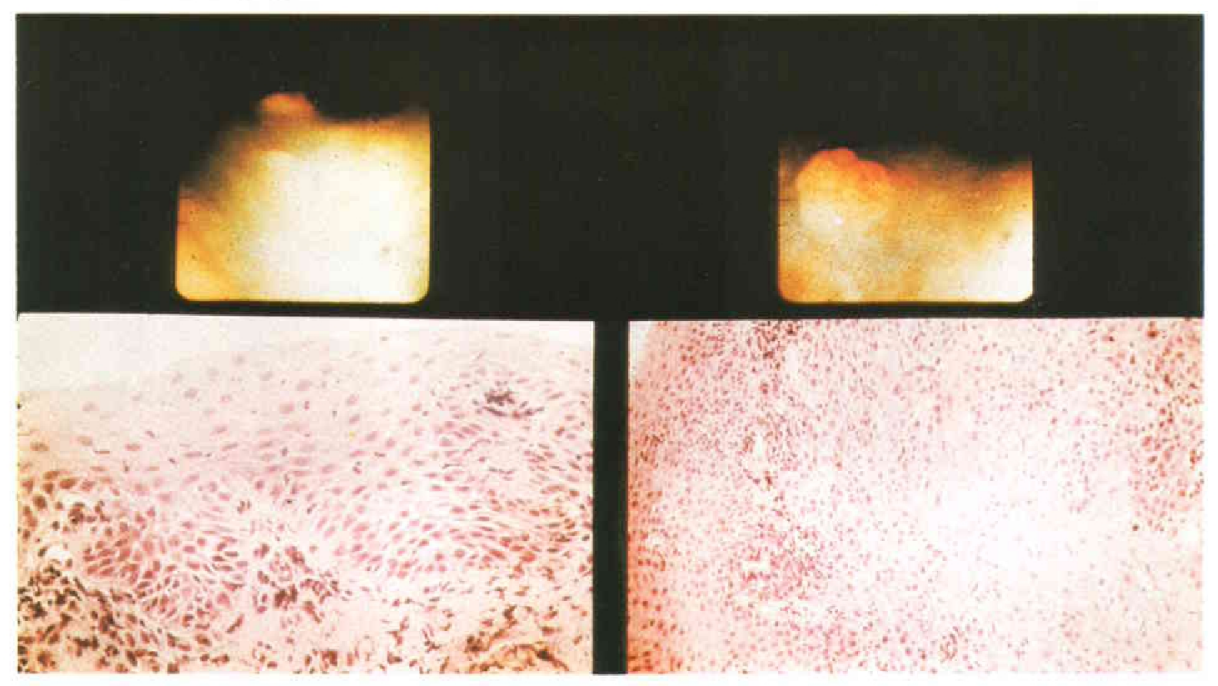


図 2 イヌ食道病変のシェーマ

1 例， 2 例は ENNG $150 \mu \mathrm{g} / \mathrm{ml} ， 6$ カ月投与, ENNG 総量 $27 \mathrm{~g}, 3$ 例， 4 例は ENNG $100 \mu \mathrm{g} /$ $\mathrm{ml}, 9$ 力月投与, ENNG 総量 $27 \mathrm{~g}$.
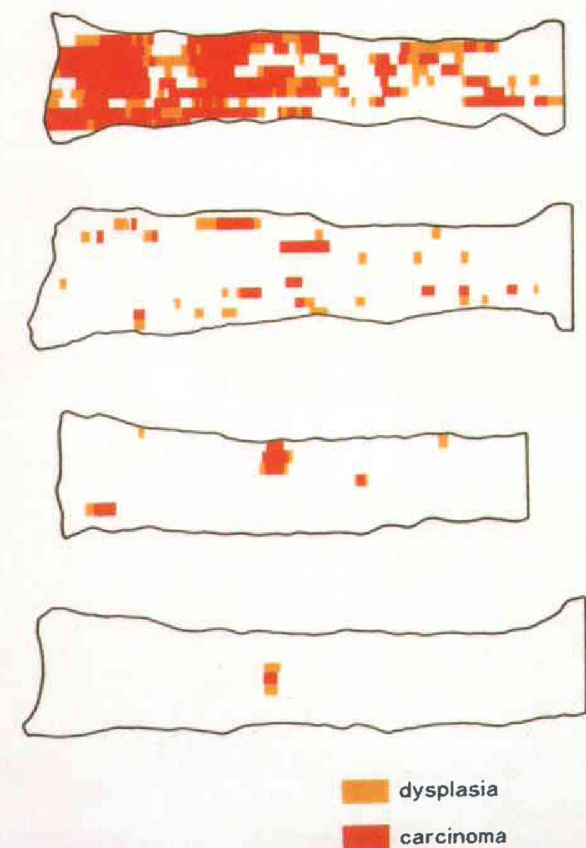

写真12 ビーグル犬食道の微小癌 $(\mathrm{H} . \mathrm{E}$ 染色, $\times 50)$ 左方の異型波と右方の癌が連続移行して いる.

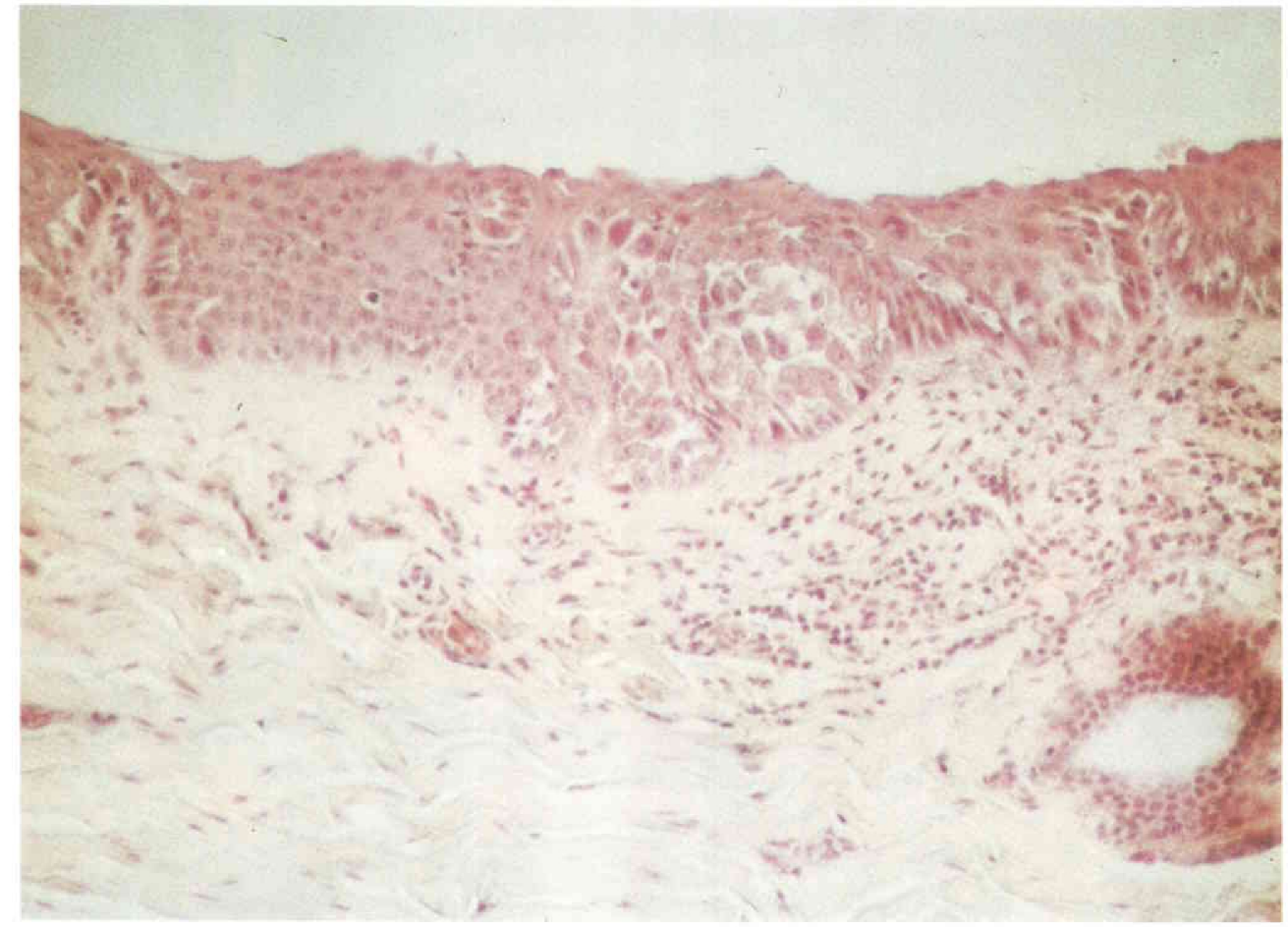


写真13 ラット食道癌に対する O-BLM (左) と三者併用療法 (右)の効果, 三者併用で癌細胞 の変性, 壞死が強く又られる。

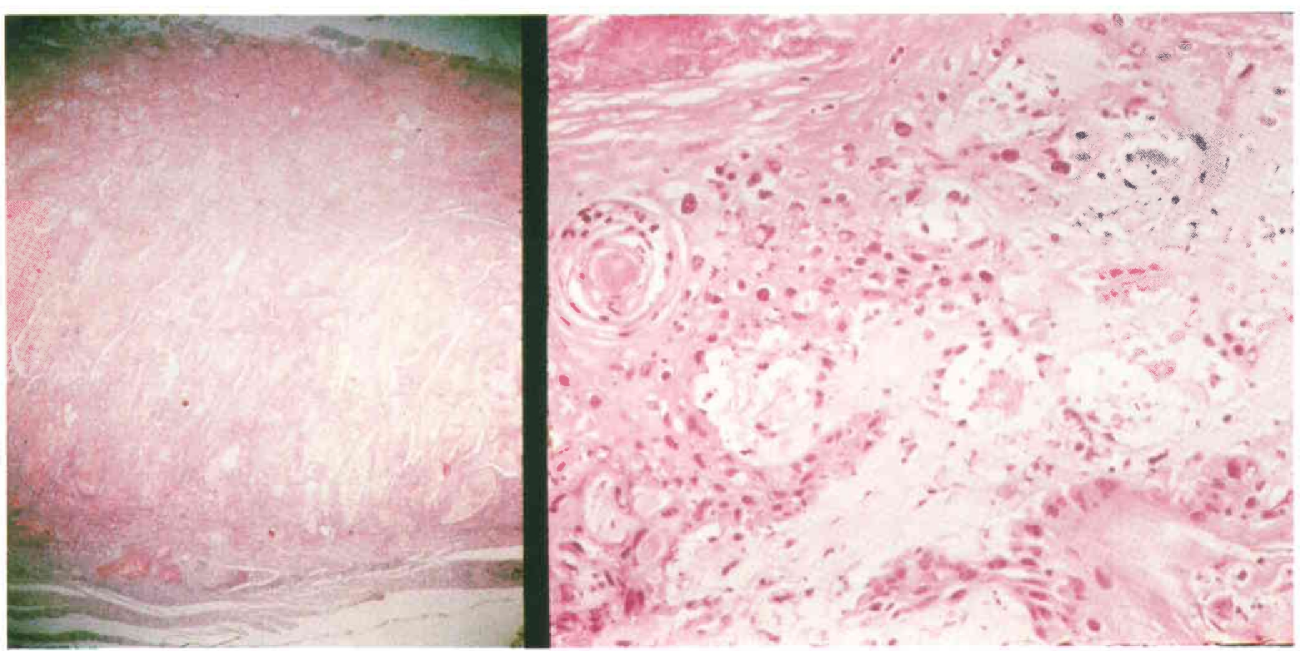

写真14 各補助療法群ラット食道の肉眼所見（三者併用群で腫瘍の発生は著しく減少してい る.)

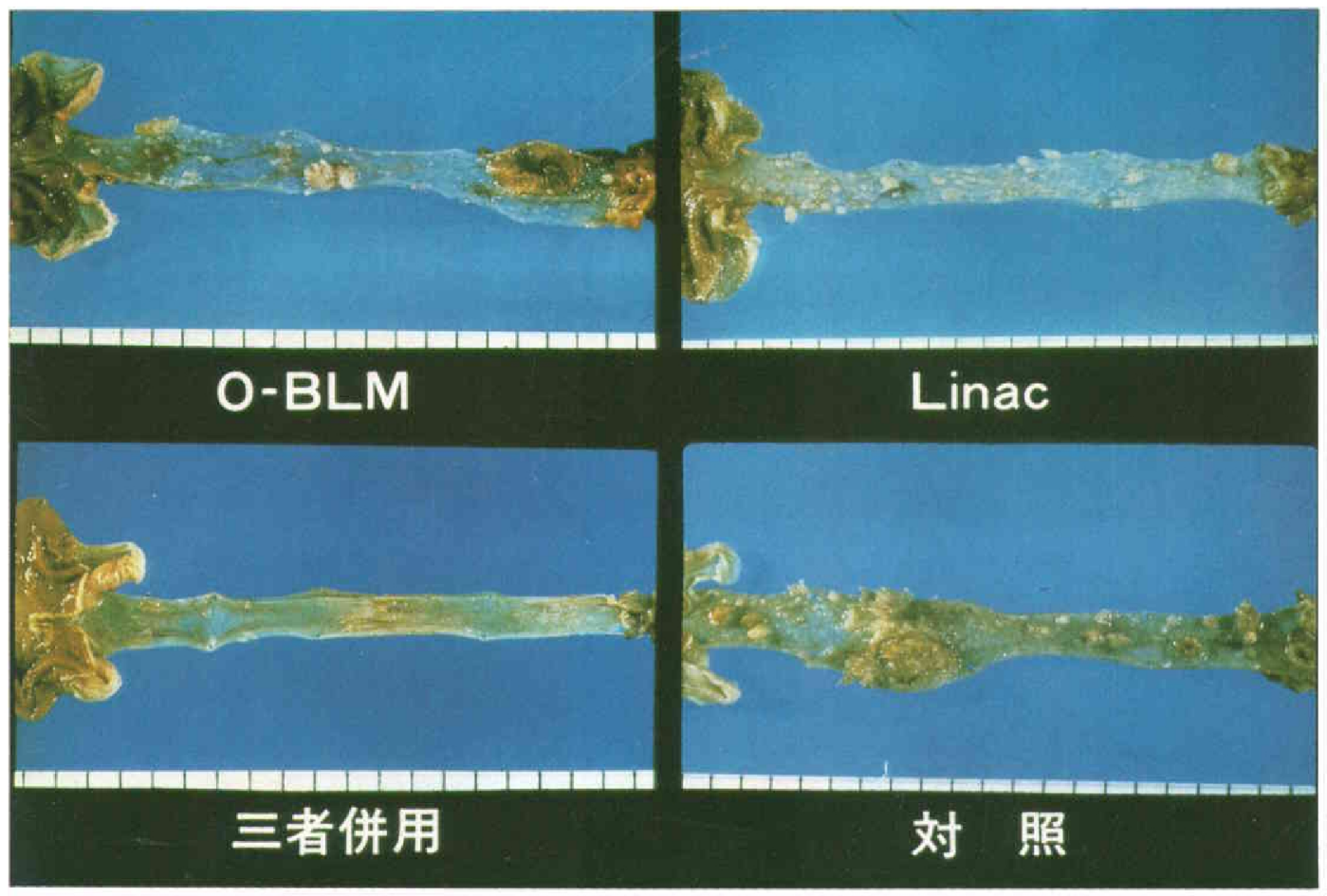


写真 3 (左) 固有食道腺導管上皮の過形成と異型化，66歳，男子，食道癌（右）導 管上皮由来と思われる微小扁平上皮癌，61歳，女子，食道癌。（H.E 染色左 $\times 200$, 右 $\times 5$ )
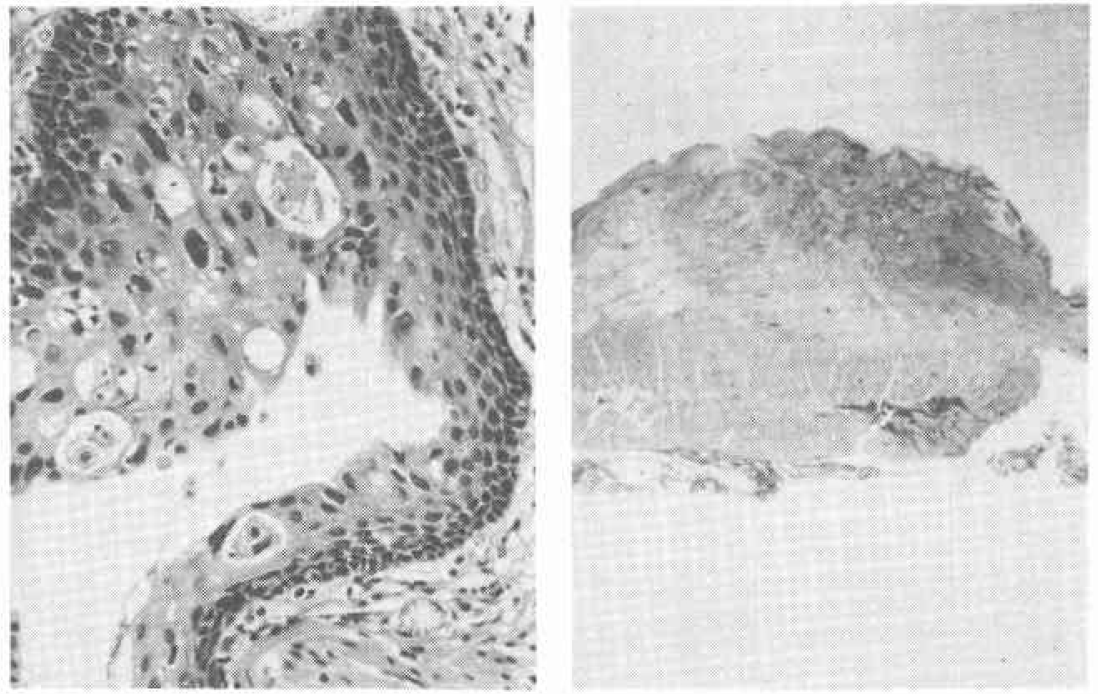

写真 5 癌, 正常上皮両細胞移行部 右に癌細胞，左に正常粘膜上皮細胞で両者は中央の 間質采細胞を介して存在した。 $(\times 3,000)$

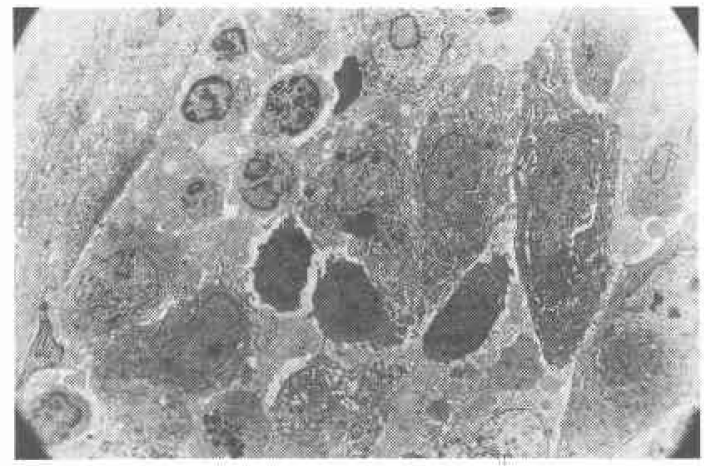

膜の存在する部にはへミデスモゾームを認めるにもか かわらず，偽足突起には認められなかった。これに対 し，単純置換型では偽足突起は汪とんど認められな かった.

すなわち, 癌細胞は多数の偽足突起を出して基底膜 を破壊して深部に進展していくことが示唆された。

2. 実験的食道癌

(1) ラット食道癌

ウイスター系雄ラットにN-メチル-N-アミルニトロ サミン(MNAN)，濃度0.003\%を飲料水として 8 週間 経口投与し，毎週 3 頭づつ屠殺剖検して25週まで食道

写真 6 癌, 正常上皮両細胞移行部の組織像

(左) 電影像 $(\times 4,000)$

(右) 同部光顕像（トルイジンブルー染色, $\times 400)$
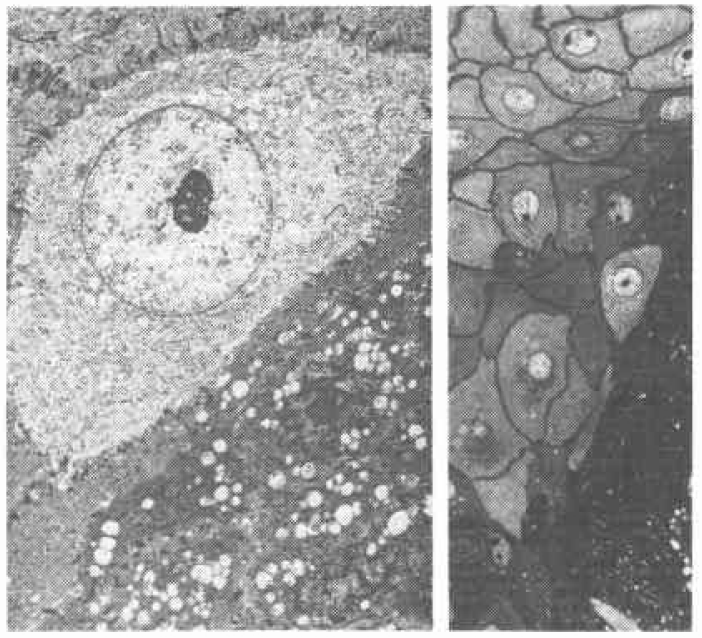

の経時的变化を検討した.

\section{(a) 組織学的検討}

投与後 5 週で初めて過形成がみられ，25週まで連続 して認められた。過形成には異型はみられず配列の变 化もなく，上皮の各層， とくに基底，傍基底細胞の増 殖がみられた（写真 8 左上）。

異型上皮は過形成のなかで細胞の異型と配列に乱れ 
写真 7 電影像基底膜を破壊する癌細胞の偽足細胞質 突起 $(\times 3,000$ 挿入 $\times 6,000)$

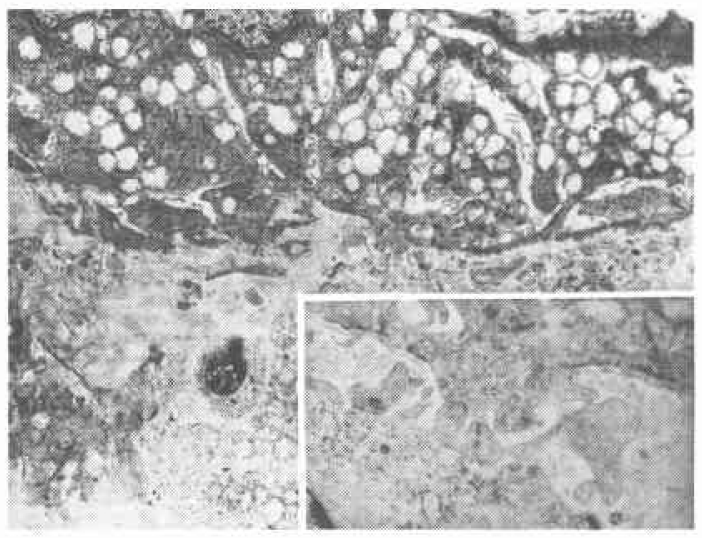

があるもので，6週より見られ基底，傍基底細胞の異 型と各層の細胞に配列の乱れがみられた，部位的には 差はなく，とくに過形成の影著なすのに多くみられた.

乳頭腫は 7 週目からみられ，10週以後ははぼ全例に みられた，食道の管腔内に向って有茥性ポリープ状に 発育し多発性であり，上皮の過形成，過角化を伴うが 細胞異型は軽度で実験終了時にも癌病巣はみられな かった。

早期の扁平上皮癌が13週で初めてみられた，写索 8 右上は粘膜下に発育した endophytic type の過形成の 上皮に被われた小癌病巣で，中央の陷凹ょり癌化して 粘膜下に侵入し巣状の病巣を作っており，すべて高分 化型であった。

军真 8 左下は，管腔内に向って発育する exophytic typeの早期癌で, 過形成から突如として单状に癌化し 分化度は前者より低く，両者とも長径は $1 \mathrm{~mm}$ 以下で あった。

写高 9 は，15週の食道肉眼所見で入口部から中部ま で乳頭畽, 早期癌が, 下部には進行癌が発生している.

進行癌は15週で初めてみられ長径 $3 \mathrm{~mm}$ 以上で樹 枝状に発育し高分化型で角化が強く筋層をこえて外膜 にまで浸潤し，また，辺縁に過形成がみられた（写索 8 右下).

腫瘍の経時的発生頻度を 5 週ごとにみると，表 3 の ごとく，5週までは腫瘍の発生はみられなかったが， 6〜10週では乳頭腫が40\%，11〜15週では86.7\%と増 加し16〜25週ではほぼ全例にみられた。早期癌は 11〜15週で13.3\%，16〜20週で33.3\%，21〜25週で $53.3 \%$ にられ, 進行癌は15週で初めてみられ, 16〜20
表 3 ラット食道癌の 5 週毎の腫崵発生頭数

\begin{tabular}{|c|c|c|c|c|c|}
\hline \multirow{2}{*}{ 成清 } & \multirow{2}{*}{ 梌䨛䫟数 } & \multirow[b]{2}{*}{ 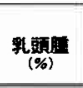 } & \multicolumn{3}{|c|}{ 䙵平上皮臣 } \\
\hline & & & 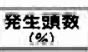 & 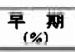 & i位 \\
\hline $1 \sim 5$ & 15 & 0 & 0 & 0 & 0 \\
\hline $6 \sim 10$ & 15 & $6(40.0)$ & 0 & 0 & 0 \\
\hline $11 \sim 15$ & 15 & $13(86.7)$ & $3(20.0)$ & $2(13.3)$ & $I(6.7)$ \\
\hline $16 \sim 20$ & 15 & $14(93.3)$ & $6(40.0)$ & $5(33.3)$ & $2(13.3)$ \\
\hline $21 \sim 25$ & 15 & $14(93.3)$ & $\mathbf{9}(60.0)$ & $8(53.9)$ & $7(46.7)$ \\
\hline
\end{tabular}

週で13.3\%，21〜25週で46.7\%と経時的に増加した， また，発生部位は乳頭睡，早期癌では差はなく，進行 癌でやや中部に多く発生する傾向がみられた15).

つぎに，食道癌発生に対する細菌性因子の影響を追 求するために，無菌ラットを用い前述と同様の方法で 実験し検討した。

表 4 のごとく, 無菌ラット14頭での腫湯発生頭数 8 例, $57.1 \%$, このうち 6 頭に乳頭腫, 2 頭に癌腫の発 生をみるのみで, すべて単発で前述普通ラットに較べ て腫癔発生頻度, 腫瘍個数も減少していた。長径は乳 頭腫は $7 \mathrm{~mm}$, 癌腫は $4 \mathrm{~mm}$ 以下で深達度は筋層まで で，いづれも下部にのみ発生し，普通ラットに較べて 著しくその趣を異にしていた。

以上の成績は，細菌性因子が食道癌の発生に少なか

表 4 MNAN 投与による普通ラットと無菌ラットの 腫瘍発生の頻度

\begin{tabular}{|c|c|c|c|c|}
\hline \multirow{2}{*}{ 群 } & \multirow{2}{*}{ 有効頼数 } & \multirow{2}{*}{ 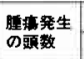 } & \multicolumn{2}{|c|}{ 䏸涪 } \\
\hline & & & 勫䌿腊 & 袖 \\
\hline 無眯ラット & 14 & $8(57.1 \%)$ & $6 / 6$ & $2 / 2$ \\
\hline 普通ラット & 15 & $14(93.3 \%)$ & $36 / 14$ & $18 / 9$ \\
\hline
\end{tabular}

らず関与していることを示するのと思われだ).

(b) 酵素組織化学的ならびにオートラジオダラフ 法による検討

食道の正常上皮と癌の生化学的，酵素組䅧化学的な 特徵はほとんと知られていない，そこで，糖代謝に関 するアルドラーゼ(阿部, 清水法), グルコースー6-リ ン酸脱水素酵素（G-6-P-DH, Rudolph, Klein 法), 還 元型ニコチンアミドダイヌクレオタイド脱水素酵素 （NADH-DH, Burstone 法）を組織化学的に検討した. また， ${ }^{3} \mathrm{H}$-thymidine $\left({ }^{3} \mathrm{H}\right.$ - $\left.\mathrm{TdR}\right), 2 \mu \mathrm{Ci} / \mathrm{g}$ を腹腔内投与 し，2 時間後に屠殺してオートラジオグラフ法による 
細胞動態をる併せ検討した。

表 5 のごとく，過形成，乳頭腫は組織化学的には正 常上皮と同じ反応態度を示し,アルドラーゼ, NADHDH は基底層に, G-6-P-DH は表層近くに活性がみら れた。 また，上皮内，上皮下にとどまる早期癌では， アルドラーゼ活性が増強し，ほかの醭素活性は减弱， 消失していた。

写真10は進行癌で, 左上は HE 染色, 右上はアルド

\section{表 5 ラット食道および病変の酵素組織化学的検索}

\begin{tabular}{|c|c|c|c|c|c|}
\hline \multirow{2}{*}{ AI } & \multicolumn{2}{|c|}{ 正晜上醉 } & \multirow{2}{*}{ 7. } & \multicolumn{2}{|c|}{ 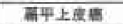 } \\
\hline & 害在屋 & D 量 & & 무 & 部 \\
\hline テルトラーを & + & - & + & \# & - \\
\hline G.6.P.DH & - & + & + & + & H \\
\hline $\mathrm{NAOH}-\mathrm{DH}$ & + & - & + & - & - \\
\hline
\end{tabular}

ラーゼで癌組織には全く活性がなく，右下の G-6-PDH は癌真珠の周囲の癌組織に強い活性がみられた。

すなわち，過形成，乳頭腫は正常上皮之同様の䣼素 活性を示すがアルドラーゼ活性は早期癌で高く，進行 癌では消失, G-6-P-DH は進行癌で高い活性を示し, 癌 の発育にともないこれら酵素活性の消失, 増強などの 変化がみられた。

一方, ${ }^{3} \mathrm{H} \cdot \mathrm{TdR}$ の取り込みは, 正常上皮では基底層に 限局し，Labeling Index (L.I.) は7.8\%にみられた。 過形成では基底層だけでなく上方にまで延長してお ク, L.I. は21.6\%, 乳頭腫は基底層と第 2 層が高率に標 識され, L.I. は35.8\% と増加するが, 癌組織では不規則 に標識細胞がみられ L.I. は16\%にみられた。

即ち, 過形成では細胞増殖帯の延長, 癌組織は不規 則な取り込みが特徴であった7).

(2) イヌ食道癌

表 6 のごとく, N-エチル·N'・ニトロ·N-ニトロソグア シジン（ENNG）を種々の濃度および期間でビーグル 犬21頭に飲料水として経口投与し, 異型上皮, 微小癌

表 6 イヌ食道癌の作製

\begin{tabular}{|c|c|c|c|c|}
\hline F & ENNG: & 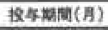 & ENNGER $(\mathrm{g})$ & 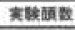 \\
\hline \multirow{3}{*}{ I } & \multirow{3}{*}{100} & 6 & 18 & 3 \\
\hline & & e & 24 & 2 \\
\hline & & 9 & 27 & 3 \\
\hline \multirow{2}{*}{ II } & \multirow{2}{*}{150} & 5 & 22.5 & 3 \\
\hline & & 6 & 27 & 3 \\
\hline III & 250 & 4 & 30 & 7 \\
\hline \multirow[t]{2}{*}{ IV } & 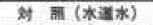 & - & - & 2 \\
\hline & \multicolumn{3}{|c|}{ It } & 23 \\
\hline
\end{tabular}

さらに遠隔転移を伴ら進行癌を作成し，その発生過程 を内視鏡, レントゲン検査で観察し,ささらに異型上皮 と癌との関係を微小癌について検討した。

進行癌を作製するには表 7 上段のごとく，100 $\mathrm{\mu g}$ / $\mathrm{ml}, 9$ 力月, $150 \mu \mathrm{g} / \mathrm{ml}, 6$ 力月投与, ともに ENNG 総量 $27 \mathrm{~g}$ が適当と思われた. $150 \mu \mathrm{g} / \mathrm{ml}, 6$ 力月投与群 では $\mathrm{a}_{3}$ で肺, 肝転移を伴うもの, $\mathrm{a}_{2}$ で肺転移やリンパ 節転移がみられた。また，組織型は大多数は高分化型 扁平上皮癌で一部，中分化型で低分化型癌は発生しな かった。

しかし，ヒトによく似た陥凹性癌を作製できたが， 病変が多く同時に胃癌を発生するなどの点から微小癌 を作ることを検討した。

表 7 下段のごとく, $100 \mu \mathrm{g} / \mathrm{ml}, 8$ 力月投与, ENNG 総量 $24 \mathrm{~g}$ では 2 頭中 1 頭に微小癌を, 同濃度で 6 カ月 投与, 総量 $18 \mathrm{~g}$ では 3 頭中 2 頭に異型上皮のみが発生 した ${ }^{8)}$ ，ところが, $250 \mu \mathrm{g} / \mathrm{ml}, 4$ 力月間, 総量 $30 \mathrm{~g}$ 投与 し12カ月で屠殺すると異型上皮は発生せず微小癌のみ 7 頭中 4 頭に発生した"9).

写真11は微小癌で経過を観察できた $100 \mu \mathrm{g} / \mathrm{ml}, 8$ カ 月投与イヌで, 左上は投与 24 力後の内視鏡所見で, 周囲に目印のため色素で青く染めた粘膜面に扁平隆起

表 7

\begin{tabular}{|c|c|c|c|c|c|c|c|c|}
\hline H & $\underset{(\mu / m / m i)}{n}$ & 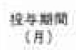 & $\begin{array}{c}\text { ENNGFe in } \\
\text { (g) }\end{array}$ & 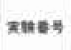 & 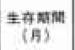 & ต $\equiv$ & 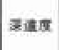 & a 15 \\
\hline \multirow{3}{*}{1} & \multirow{3}{*}{100} & \multirow{3}{*}{9} & \multirow{3}{*}{27} & 6 & 21 & 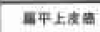 & $\overline{a_{t}}$ & 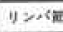 \\
\hline & & & & 7 & 16 & 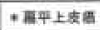 & $m$ & \\
\hline & & & & 8 & 88 & 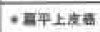 & sim & \\
\hline \multirow{3}{*}{ ॥ } & \multirow{3}{*}{150} & \multirow{3}{*}{6} & \multirow{3}{*}{27} & 12 & 20 & 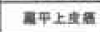 & $a_{1}$ & 勘・开 \\
\hline & & & & 13 & 34 & 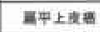 & a) & m \\
\hline & & & & 14 & 40 & 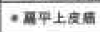 & ar & 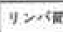 \\
\hline \multirow{2}{*}{ iv } & \multirow{2}{*}{ 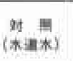 } & \multirow{2}{*}{$=$} & \multirow{2}{*}{-} & 22 & 12 & $=$ & $=$ & \\
\hline & & & & 23 & 12 & - & - & \\
\hline
\end{tabular}

ビーグル犬に微小蜢を作製する条件

\begin{tabular}{|c|c|c|c|c|c|c|c|}
\hline$m$ & 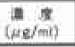 & 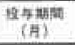 & $\begin{array}{c}\text { ENWGER: } \\
\text { (s) }\end{array}$ & Kans 4 & $\begin{array}{c}\text { 生若 } \\
\text { (A) }\end{array}$ & $\pi x$ & rengen \\
\hline \multirow{5}{*}{ I } & \multirow{5}{*}{100} & \multirow{3}{*}{6} & \multirow{3}{*}{ IB } & 1 & 37 & 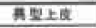 & $=$ \\
\hline & & & & 2 & 31 & A箸上皮 & - \\
\hline & & & & 3 & 13 & - & - \\
\hline & & \multirow{2}{*}{8} & \multirow{2}{*}{24} & 4 & 49 & - & $=$ \\
\hline & & & & 5 & 48 & 中㬓年上皮需 & ep \\
\hline \multirow{3}{*}{ "I } & \multirow{3}{*}{150} & \multirow{3}{*}{5} & \multirow{3}{*}{22.5} & 9 & 31 & 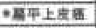 & ep \\
\hline & & & & 10 & 34 & 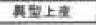 & $=$ \\
\hline & & & & II & 37 & 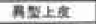 & - \\
\hline \multirow{7}{*}{ III } & \multirow{7}{*}{230} & \multirow{7}{*}{4} & \multirow{7}{*}{30} & 15 & 12 & 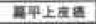 & $e g$ \\
\hline & & & & 16 & 12 & 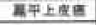 & $\min$ \\
\hline & & & & 17 & 12 & - & $=$ \\
\hline & & & & 18 & 12 & 占平上皮视 & $\operatorname{mim}$ \\
\hline & & & & 19 & 12 & 掫年上虚曋 & $\mathrm{mem}$ \\
\hline & & & & 20 & 12 & $=$ & $=$ \\
\hline & & & & 21 & 12 & + & $=$ \\
\hline
\end{tabular}


があり表面は平坦で少し発赤のある所見が認められ, 左下の生検所見では上皮の基底層から傍基底層に異型 細胞が認められ異型上皮と診断された。右上は，さら に30カ月後の同一病変の内視鏡所見で, 扁平隆起は増 大し表面が凹凸不整で軽度の発赤がみられ，右下の生 検所見では角化傾向の乏しい扁平上皮癌であった。投 与後の剖検での組織所見は中分化型の上皮内扁平上皮 癌で，異型上皮と隣接し明瞭に両者は区別できた。 た, 同時に微小起癌, ビラン性癌も発生し癌の 形態はヒト早期食道癌とよく類似していた。

图 2 は剖検食道をすべて $5 \mathrm{~mm}$ 幅で全割し, 発生し た癌と異型上皮との関係を検討したシェーマで, 最上 段は進行癌を作製する条件の $150 \mu \mathrm{g} / \mathrm{ml}$, ENNG $27 \mathrm{~g}$ 投与，20カ月で屠殺した食道で上部から下部にかけて 赤で示す癌と黄色で示す異型上皮が多数認められ, 同 じ条件の 2 列目の食道も同様の病変がみられる.下の 2 列に示すように同じ $27 \mathrm{~g} て ゙ も 100 \mu \mathrm{g} / \mathrm{ml}$ と低濃度に すると癌, 異型上皮ともに発生数は著しく減少してい る. また, $150 \mu \mathrm{g} / \mathrm{ml}, 22 \mathrm{~g}$ とすると癌と異型上皮の散 在，さらに $18 \mathrm{~g}$ と投与量を少くすると異型上皮のみの 散在と, ENNG 濃度と総量のちがいによって進行癌か ら異型上皮のみのものまで作製することができた。

写真12は低濃度投与イヌに認められた極めて徵小な 扁平上皮癌で, 左に異型上皮を認め, 右の癌と連続し ている.

そこで, 癌と異型上皮との位置的関係を微小癌につ いて検討した。

表 8 のごとく，20病変中癌の両端が異型上皮に連続 隣接するもの 4 個，どちらかの一端が連続隣接するも の 7 個, このらち $3 \mathrm{~mm}$ 以下の 9 個, $3 \sim 5 \mathrm{~mm}$ の 4 個の計 13 病変中 7 病変が両端あるいは一端が異型上皮 に連続隣接していた。

この事実はイ邓の実験食道癌の発生は異型上皮と密

表 8 イヌ食道癌と異型上皮との関係

\begin{tabular}{|c|c|c|c|c|}
\hline \multirow{3}{*}{ 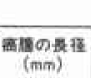 } & \multirow{3}{*}{ 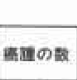 } & \multicolumn{3}{|c|}{$(100 \mu \mathrm{\mu} / \mathrm{mm}, 150 \mu \mathrm{\mu} / \mathrm{m} /)$} \\
\hline & & \multirow{2}{*}{\multicolumn{2}{|c|}{ 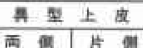 }} & \multirow{2}{*}{ D传 $t$} \\
\hline & & & & \\
\hline-3 & 9 & 2 & 4 & 3 \\
\hline $3 \sim 5$ & 4 & 0 & 1 & 3 \\
\hline $5-$ & 7 & 2 & 2 & 3 \\
\hline it & 20 & 4 & 7 & 9 \\
\hline
\end{tabular}

接なる関係の存することを強く示晙するものと考学ら れた8).

\section{II. 食道癌の補助療法の検討}

\section{1. 補助療法の臨床的検討}

教室での食道癌症例は昭和 57 年 6 月迄の過去 8 年間 に119例が入院し, 切除57例，切除率47.9\%, 術死 1 例, 術死率 $1.7 \%$ である. 進行癌が多く ${ }^{10)}$, 種々なる補助療 法を行っているが，単開胸となった $\mathrm{A}_{3}$ 症例にパナ化 薬配合オイルブレオマイシン(O-BLM)を経口投与し， 著効を得て 2 年後の現在, 通過障害むなく日常生活を 営んでいる症例を释験して以来, 局所に吸収されるOBLM の効果を考㦄し術前合併療法の一手段としてい る.このパナ化薬配合 O.BLM の停滞時間は㹨窄の程 度により時間は異なるが，少くとも 2 時間は局所に停 滞し, 各組織内濃度す正常上皮の平均 $0.25 \mu \mathrm{g} / \mathrm{ml}$ より 癌腫は平均 $0.45 \mu \mathrm{g} / \mathrm{ml}$ と高く,リンパ節にも平均 0.31 $\mu \mathrm{g} / \mathrm{ml}$ と取り込みがみられた。

ところで, 高王酸素療法により組織酸素分王をあげ ると放射線感受性が高まること ${ }^{11)}$ ，その直接抗腫瘍効 果と放射線, 抗癌剤との併用があること年などが知ら れているので, 現在教室では, 肺線維症の少ないとさ れる O-BLM 経口投与に高任酸素療法, 放射線療法の 三者併用を行っている.

表 9 は切除症例の術前合併療法の組織効果である が, $\mathrm{Ef}_{2}$ は照射のみ $38.5 \%$, 照射 + BLM は $25 \%$, 照射十

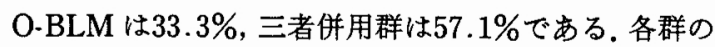
組織効果の明瞭な統計的有意差は症例数が少なくて無 いが，三者併用補助療法の一手段として有効と思わ れ，今後症例を重ねて検討していきたい。

表 9 術前合併療法の組樴に対する治療効果

\begin{tabular}{|c|c|c|c|c|}
\hline 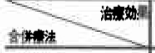 & Ef 1 & Ef 2 & Ef 3 & it \\
\hline Rascation & $15(57.7 \%)$ & $10(38.5 \%)$ & 1 (3.8\%) & 26 \\
\hline $\operatorname{Rad}+\mathrm{BLM}$ & $3(73.0 \%)$ & $1(25.0 \%)$ & $=$ & 4 \\
\hline Rad toil-a.M & $4(66.7 \%)$ & $2(33.3 \%)$ & - & 6 \\
\hline Rad toil-aum+arp & $3(42.9 \%)$ & $4(57.1 \%)$ & - & 7 \\
\hline at & $26(60.5 \%)$ & $16(37.2 \%)$ & 1 (2.3\%) & 43 \\
\hline
\end{tabular}

2. 補助療法が実験的食道癌の発生と発育過程に及 ぼす影響について

1. 化学療法 (O-BLM)

実験は前述のラット食道癌作製法に順じた。図3の ごとく，I 群は MNAN 投与開始 2 週より O-BLM, $0.5 \mathrm{mg} / \mathrm{kg}$, 週 3 回を 24 週まで経口投与し, II 群は早期 癌の発生する前の11週から投与した. MNAN のみ投 与したものを対照群とした。 
図 3 ラット食道癌に対する補助療法の効果
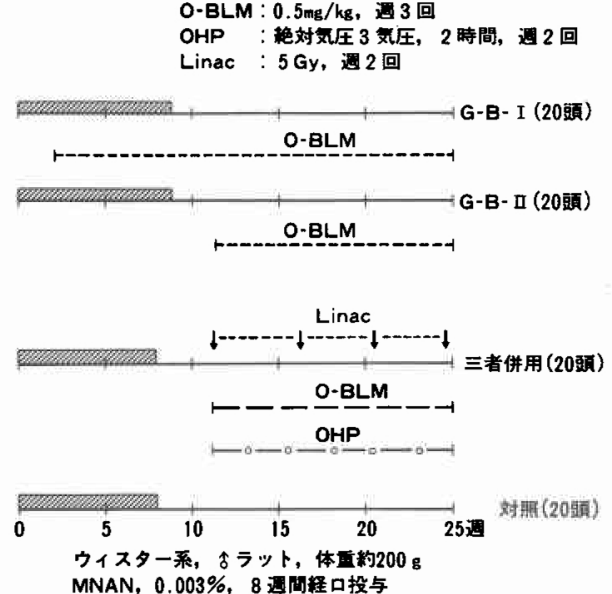

MNAN，0.003\%，8㴓间経口投与

食道癌発生に対する効果は表10のごとくで，対照群 $57.9 \%$ に対し，I群は $47 \%$, II 群は $26.3 \%$ とその発生 率は明らかに抑制されて括り，とくに進行癌は対照群 に較べて有意に減少していた。

写真 3 左は O-BLM 投与群に発生した進行癌の組織 像で，好酸性に染る角化部分が著明に増加して扣り， 下方の癌の部分は腫赏細胞の変性はみられるが壊死に 致る細胞はあまり湿著ではない。

また，癌の面積に占める角化の割合をみると○ー BLM 投与群では, 対照群に較べて早期癌, 進行癌とも 極めて角化の増加がみられた，深達度と組織型では角 化率 $50 \%$ 以上のものが早期癌, 進行癌では $27 \%$ によ れ，高分化型扁平上皮癌にとくに効果がみられた。

2. 高任酸素療法 (OHP)

食道癌発生に対する効果は対照群 $57.9 \%$ に対し， OHP 単独群とOHP+O-BLM 群ともに55.6\%と抑制 効果はみられず高压酸素の抗腫湯効果, 併用効果は今 回の実験では差異はなかった。しかし肺線維症の懸念 はなかった。

3. 放射線療法 (Linac)

10 15週までの早期癌発生時（I 群）と進行癌とな

表10 補助療法のラット食道癌発生に対する効果

\begin{tabular}{|c|c|c|c|c|c|}
\hline \multirow{2}{*}{$\mathrm{n}^{\mathrm{n}}$} & \multirow{2}{*}{ 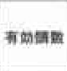 } & \multirow{2}{*}{$\begin{array}{l}\text { mata生 } \\
\text { 西 a }\end{array}$} & \multicolumn{2}{|c|}{ 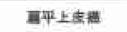 } & \multirow{2}{*}{ it } \\
\hline & & & $\$ N$ & 请 $\overline{5}$ & \\
\hline$G-B-I$ & 17 & 17 & 4 & 4 & $8(4+N)$ \\
\hline $6-B-11$ & 19 & 18 & 3 & 2 & 5 (as $-4 \mathrm{~s})$ \\
\hline 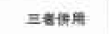 & 16 & 16 & 5 & 0 & 5 (a) $3 \mathrm{~s}$ \\
\hline 3) 目 & 19 & 19 & 2 & 9 & $11 \mathrm{kr.25}$ \\
\hline
\end{tabular}

る20週より剖検前の24週（II群）までの時期に Linac を総量30Gy 照射した。

食道癌発生に対する効果は, I 群では $25 \%$ で早期癌, 進行澏之もに対照群よりその発生率は低く，II群でも 早期癌が多く進行癌が少なく放射線の効果があった。

また，癌組織の変性壊死効果も II 群では効果（一) $53.3 \%$ ，(+) $26.7 \%$ ，(丮） $20 \%$ と半数近くにみられ た。しかしながら線量を $30 \mathrm{~Gy}$ 以上照射しても治療効 果の上昇はみられなかった。

4. 三者併用療法

図3のごとく，三者併用を検討すると，表10のごと く食道癌の発生は 16 頭中 5 頭， $31.3 \%$ で，しかむ進行 癌が 1 例もなく組織効果も写真13右のごとく，表層部 は角化が高度で, 癌細胞むほとんと㠜固壊死に陥って, 癌真珠の周囲にごく少数の生存する腫愓細胞がみられ 顕著な治療効果が認められた。

写真14は, 各補助療法群の剖検時の食道標本である が，対照群に較べて補助療法群は明らかに腫瘍発生を 抑制して括り，とくに三者併用は著明な抑制効果がみ られる。

\section{むすU゙}

以上, 食道癌の発生之治療に関して, 我々の研究成 績の一端を述べたのであるが，これを一括すると，大 要次のごとくである.

I ．1．ヒト，イヌ，ラットの食道癌は異型上皮を前 癌病変として発生することが示唆された。

2. 七上食道胃接合部の予備細胞增殖を伴う扁平上 皮化生は癌発生母地の 1 つとして示唆された。

3. 七上食道癌の上皮内進展部には間質系細胸が介 在し，基底膜は偽足突起によって破壊され，㳭部に進 展していくことが示唆された。

4. 発癌の促進因子の一つとして細菌の関与が示唆 された。

5. 癌の発生に伴い, アルドラーゼ, G-6-P-DH, NADH-DH などの酵素活性の消失, 増強が組織化学的 にみられた。

II . 1. O-BLM, Linac 照射は実験食道癌の発生, と くに進行癌を有意に抑制させた．また，癌組織に対し， O-BLM は角化を促進し, Linac 照射は変性, 罜死を来 たした。

2. 三者併用療法は実験食道癌ばかりでなく，ヒト食 道癌の補助療法として有効であった。

3.ラット拈よびイヌ実験食道癌はヒト食道癌実験 モデルとして治療法の開発に有用である。 
この宿題報告を終るにあたり, 直接御指導, 御鞭達下さ れ，さらに講演の機会を御与え下さいました本総会々長, 恩 師代田明郎教授に深甚なる謝意を表すととるに，日夜研究 に没頭してくれた，笹島耕二，田久保海誉，松倉則夫，岡崎 滋樹, 森野一英, 谷口善郎, 小島範子, 無菌生物研究室, 高 王酸素治療室, また, 御協力いたたいた本学放射線科, 恵畑 欣一教授, 埼玉がんセンター病院, 藤田吉四郎副院長に謝意 を表します。

\section{文献}

1）鍋谷欣市, 入村哲也, 伊達 靖 : 早期食道癌, 臨胸 外 $1: 579-588,1981$

2) Takubo K, Tsuchiya S, Shirota A, et al: Dysplasia and reserve cell hyperplasia-like changes in human esophagus. Acta Pathol Jpn $31: 999-1013,1981$

3）山下精彦, 田久保海誉, 笹島耕二ほか：食道癌の発 生母地について。 日外会誌 81 (臨時増刊号): 163,1980

4) Takubo K: Squamous metaplasia with reserve cell hyperplasia in esophagogastric junction zone. Acta Pathol Jpn $31: 349-359$, 1981

5）岡崎嵫樹：N・メチル-N・アミルニトロサミンによ 万実験食道癌の発生の経時的研究. 日消病会誌 $78: 1889-1895,1981$

6) Sasajima K, Taniguchi $Y$, Adachi $K$, et al :
Sequential studies on esophageal carcinoma induced in conventional and germfree rats by $\mathrm{N}$-methyl-N-amylnitrosamine, Recent Advances in Germfree Research, Tokai University Press, 1981, p657-660

7）谷口善郎，笹島耕二，山下精彦ほか：実験食道癌の 組織化学法ならびにオートラシオグラフ法による 研究. 第71回日本病理学会, 1982

8）森野一英：N.エチル-N'-ニトロソグアニシン (ENNG)によるイヌ食道癌実験系の検討，日消病 会誌 $79: 765-771,1982$

9) Takubo, K., Shisa H, Sasajima K, et al : Early changes of dog esophageal mucosa induced by $\mathrm{N}$-ethyl-N'-nitro-N-nitrosoguanidine. Gann 72 : $880-885,1981$

10）山下精彦, 谷口善郎, 笹島耕二ほか：食道癌におけ る早期診断の困難性について。因大誌 48 ： 891, 1981

11) Gray LH, Conger AD, Ebert $M$, et al: The concentrative of oxygen dissolved in tissues at the time of irradiation as a factor in radiotherapy. Brit J Radiol 26 : 638-698, 1953

12) Mori K: Study on adjuvant therapies in cancer chemotherapy. Especially on the combination of hyperthermia and hyperbaric oxygenation. Nagoya J Med Sci $29: 275-316,1967$ 